
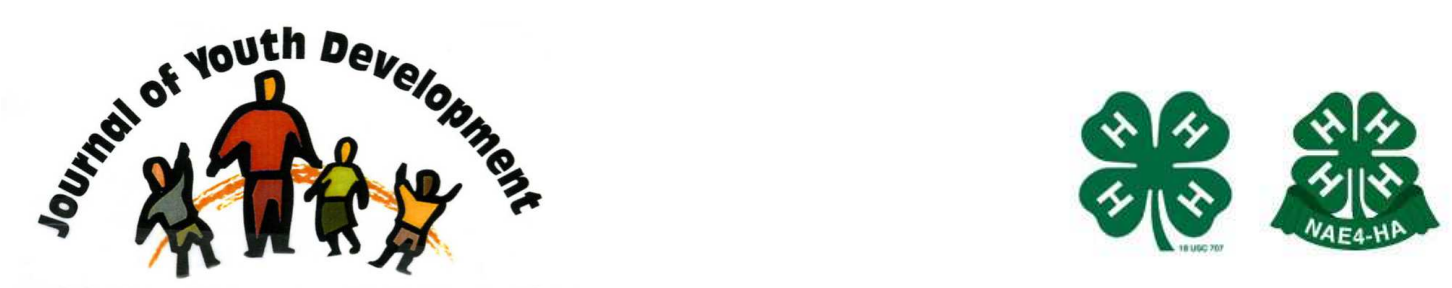

Bridging Research \& Practice

\title{
"...and my World:" \\ Perceptions of County Educators and Volunteers toward International 4-H Programs
}

\author{
Jeff Sallee \\ 4-H Youth Development \\ Oklahoma State University \\ Stillwater, OK \\ jeff.sallee@okstate.edu
}

Sarah Lancaster

Plant and Soil Science

Oklahoma State University

Stillwater, OK

sarah.lancaster@okstate.edu 


\title{
JOURNAL OF YOUTH DEVELOPMENT \\ bridging research and practice

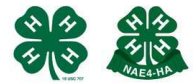

\section{"...and my World:" \\ Perceptions of County Educators and Volunteers toward International 4-H Programs}

\author{
Jeff Sallee and Sarah Lancaster \\ Oklahoma State University
}

\begin{abstract}
The phrase "...and my world" was added to the 4-H pledge in 1973, forever solidifying 4-H's commitment to international programming and global citizenship. In 2008, Oklahoma 4-H began to consider revitalizing its international outreach. After researching the barriers to International 4-H projects, Oklahoma 4-H educators and volunteers were surveyed to discover their interests in this area with the intent of beginning a renewed International 4-H program with educator and volunteer support. The survey results indicate that 4- $\mathrm{H}$ volunteers and youth educators prefer short term International educational programs that focus on cultural awareness and servicelearning for older youth.
\end{abstract}

\section{Introduction}

The phrase "...and my world" was added to the 4-H pledge in 1973, forever solidifying 4-H's commitment to international programming and global citizenship. This phrase, had already been added to the pledge on local and state levels, and was added officially as a result of a grassroots outcry from 4-H members across the nation (Wessel \&Wessel, 1982). 4-H was working internationally long before 1973, with club work beginning in Great Britain in 1921 and followed by Denmark and Finland in 1924 and 1926. By 1925, Canada claimed 1,000 clubs with 100,000 boys and girls (Reck, 1951).

The growth of 4-H across the globe was impressive, but it didn't affect the lives of many 4-H members in the United States. This was changed in 1948 with the beginning of the International Farm Youth Exchange (IFYE). The IFYE program sent delegates around the world to live with host families, work on their farms, and become immersed in their culture for up to six months. The IFYE program was reciprocal and brought youth from host countries to the United States for similar opportunities. IFYE was eventually changed to the International 4-H Youth Exchange (IFYE) in order to reach beyond its agricultural roots. Since that time, other international 4-H programs have come and gone with similar objectives. 4-H has trained Peace Corp volunteers, developed rural youth clubs around the globe, and organized caravans of 
youth for short-term international experiences (Wessel \& Wessel, 1982). In 1967 the Youth Development Project (YDP) combined elements of IFYE and the Peace Corps, and sent youth to Africa, Latin American, and the Philippines. Since its inception in 1972, the Japanese Exchange program has engaged 35 states to host over 30,000 Japanese teenagers and sent more than 6,000 American 4-H members to Japan (Radhakrishna \& Ingram, 2005). 4-H even negotiated an exchange with the Soviet Union and sent members beyond the iron curtain in 1976 (Wessel \& Wessel, 1982).

Through all this growth in international programming, 4- $\mathrm{H}$ has created global awareness during travel and exchanges. Conversely, international 4-H programs are often fragmented and isolated from mainstream 4-H (Etling, Reaman \& Sawi, 1993). The barriers causing the isolation of International 4-H have been identified as expense, lack of a clearly defined project, agent resistance to international activities, problems with state program leadership, inadequate communication, deadlines, and limited opportunities for adults who might travel with youth to provide support (Boyd, et al., 2001; Etling, Reamann, \& Sawi, 1993).

With the beginning of the 21st century, Oklahoma, like other state 4- $\mathrm{H}$ programs, dropped its international efforts due to a lack of interest from 4-H members, families, and personnel. In 2008, Oklahoma 4-H began to consider revitalizing its international outreach. After researching the barriers to International 4-H, Oklahoma 4-H educators and volunteers were surveyed to discover their interests in this area with the intent of beginning an International 4-H program with educator and volunteer support.

\section{Methodology}

An Internet survey was developed to explore county educator and volunteer perceptions of starting an international 4-H program. The survey instrument was given face validity by review from a panel of experts. The survey instrument was created to determine the perceptions of the 4- $\mathrm{H}$ volunteers and educators. Quantitative and qualitative questions were asked concerning the interest in, and design of, an international 4-H program. An email was sent to all Oklahoma Cooperative Extension Service Educators (201) and all certified club leaders with an email address on record (107).

\section{Findings}

The survey had a combined response rate of 40.93 percent, with a $65 \%$ response rate from the volunteers and $31 \%$ from County Educators (Table 1). Often $4-\mathrm{H}$ volunteers and educators are also parents of $4-\mathrm{H}$ members. This is evident in that $29.6 \%$ of the respondents identified themselves as $4-\mathrm{H}$ parents. The survey respondents were $76 \%$ female, $54 \%$ county educators, $45 \%$ volunteers, and their years of service to $4-\mathrm{H}$ ranged from less than 5 years to over 20 years (Table 2 ).

Table 1

Summary of survey response rage $(N=115)$

\begin{tabular}{|l|l|l|l|l|l|}
\hline Audience & $\begin{array}{l}\text { \# Emails } \\
\text { Sent }\end{array}$ & $\begin{array}{l}\text { \# Emails } \\
\text { Undeliverable }\end{array}$ & \# Surveyed & $\begin{array}{l}\text { \# Surveys } \\
\text { Remitted }\end{array}$ & $\begin{array}{l}\text { \% Surveys } \\
\text { Remitted }\end{array}$ \\
\hline Educators & 201 & 0 & 201 & 63 & 31.34 \\
\hline Volunteers & 107 & 27 & 80 & 52 & 65.00 \\
\hline Total & $\mathbf{3 0 8}$ & $\mathbf{2 7}$ & $\mathbf{2 8 1}$ & $\mathbf{1 1 5}$ & $\mathbf{4 0 . 9 3}$ \\
\hline
\end{tabular}


Table 2

Summary of respondent demographics $(N=115)$

\begin{tabular}{|l|c|c|}
\hline 4-H Affiliation & Frequency & Percent \\
\hline & & \\
\hline 4-H Volunteer & 52 & 45.2 \\
\hline Extension Educator & 63 & 54.8 \\
\hline Parent/Volunteer or Parent/Educator* & 34 & 29.6 \\
\hline Gender & & \\
\hline Male & 27 & 23.5 \\
\hline Female & 88 & 76.5 \\
\hline Years of Service & & \\
\hline Less than 5 & 33 & 28.7 \\
\hline $5-10$ & 29 & 25.2 \\
\hline $11-15$ & 12 & 10.4 \\
\hline $15-20$ & 14 & 12.2 \\
\hline Over 20 & 27 & 23.5 \\
\hline
\end{tabular}

*4- $\mathrm{H}$ volunteers and Extension Educators who are also 4- $\mathrm{H}$ parents. Duplicates from 4-H Volunteers and Extension Educators

\section{Interest in International 4-H}

The questions presented in Table 3 were answered with a one to five rating on a Likert-type scale with one being "Definitely No" and five being "Definitely Yes". The data in the table are the mean ranking from the identified response group. Respondents indicated an interest in providing international experiences for youth through the Oklahoma 4-H program. Parent and volunteer responses averaged over 4.0 and educator responses were over 3.5 on all positive questions (Table 3 ).

Table 3

Respondent interest in international 4-H

Responses were on a scale from 1 to 5 where $1=$ definitely No and $5=$ definitely Yes $(N=115)$

\begin{tabular}{|l|c|c|c|c|c|}
\hline \multicolumn{1}{|c|}{ Respondent Interest } & Volunteer & Educator & Parent & $\begin{array}{c}\text { Combined } \\
*\end{array}$ & $\begin{array}{c}\text { Standard } \\
\text { Deviation } \\
\text { Combined } \\
*\end{array}$ \\
\hline $\begin{array}{l}\text { Oklahoma 4-H should offer an } \\
\text { international experience. }\end{array}$ & 4.16 & 3.87 & 4.19 & 4.01 & .871 \\
\hline $\begin{array}{l}\text { International experiences are } \\
\text { important part of youth development. }\end{array}$ & 4.10 & 3.81 & 4.19 & 3.96 & .990 \\
\hline $\begin{array}{l}\text { Oklahoma 4-H should offer a } \\
\text { international hosting program. }\end{array}$ & 4.20 & 3.89 & 4.25 & 4.04 & .865 \\
\hline $\begin{array}{l}\text { Oklahoma 4-H should offer a } \\
\text { international sending program. }\end{array}$ & 4.12 & 3.69 & 4.13 & 3.88 & 1.00 \\
\hline $\begin{array}{l}\text { Oklahoma 4-H should not offer } \\
\text { international programs. }\end{array}$ & 1.73 & 1.84 & 2.07 & 1.79 & 1.07 \\
\hline
\end{tabular}

*Volunteer and Educator only. Responses of parents were not duplicated. 


\section{Design of an International Experience}

The questions presented in Table 4 sought to determine the respondents' perceptions of a quality international experience. Questions were answered with a one to five rating on a Likerttype scale with one being "Not Important" and five being "Very Important". The data in the table are the mean answer from the indicated response group. The most positive responses were toward creating a program with strong educational components based in study, cultural awareness and educational tours. Respondents also indicated a preference for youth to have a college credit option for participation and to include a service-learning component during the experience (Table 4).

Table 4

Respondent opinion of international 4-H program design

Responses were on a scale from 1 to 5 where $1=$ definitely No and $5=$ definitely Yes $(N=115)$

\begin{tabular}{|l|l|l|l|l|l|}
\hline \multicolumn{1}{|c|}{ Program Design } & Volunteer & Educator & Parent & Combined* & $\begin{array}{l}\text { Standard } \\
\text { Deviation } \\
\text { Combined* }\end{array}$ \\
\hline $\begin{array}{l}\text { Oklahoma 4-H Personnel/staff should } \\
\text { attend with the youth }\end{array}$ & 4.12 & 3.90 & 4.00 & 4.01 & 1.13 \\
\hline $\begin{array}{l}\text { Youth should stay with international } \\
\text { families when abroad }\end{array}$ & 3.76 & 3.75 & 3.69 & 3.76 & 0.95 \\
\hline $\begin{array}{l}\text { Youth should not stay with families } \\
\text { when abroad }\end{array}$ & 2.55 & 2.43 & 2.63 & 2.49 & 1.26 \\
\hline $\begin{array}{l}\text { Youth should participate in Cultural } \\
\text { Tours }\end{array}$ & 4.45 & 4.60 & 4.69 & 4.55 & 0.61 \\
\hline $\begin{array}{l}\text { Youth should study the country before } \\
\text { traveling }\end{array}$ & 4.64 & 4.56 & 4.81 & 4.60 & 0.63 \\
\hline $\begin{array}{l}\text { Youth should participate in service } \\
\text { learning while abroad }\end{array}$ & 4.33 & 4.08 & 4.44 & 4.20 & 0.85 \\
\hline $\begin{array}{l}\text { Youth should participate in } \\
\text { educational tours while abroad }\end{array}$ & 4.47 & 4.63 & 4.56 & 4.58 & 0.60 \\
\hline $\begin{array}{l}\text { Youth should have the option to } \\
\text { receive college credit for their } \\
\text { experience }\end{array}$ & 4.41 & 4.11 & 4.50 & 4.27 & 0.77 \\
\hline $\begin{array}{l}\text { Youth should only travel to English } \\
\text { speaking countries }\end{array}$ & 2.78 & 2.37 & 3.00 & 2.60 & 1.19 \\
\hline
\end{tabular}

*Volunteer and Educator only. Responses of parents were not duplicated.

\section{Participant Age}

Respondents were allowed to select more than one age group in response to the question "What is an appropriate age for international 4-H program participants. Responses were extremely consistent, as 103 of 115 respondents indicated ages 16-17 and 88 respondents indicated participants should be over age 18. A small percentage indicated any age under 16 years old (Table 5 ). 
Table 5

Respondent opinion of appropriate age for international 4-H program participants

Respondents were asked to select all ages they believed to be appropriate $(N=115)$

\begin{tabular}{|l|c|c|c|c|c|c|c|c|}
\hline $\begin{array}{c}\text { Age } \\
\text { Range }\end{array}$ & \multicolumn{2}{|c|}{ Volunteer } & \multicolumn{2}{c|}{ Educator } & \multicolumn{2}{c|}{ Parent } & \multicolumn{2}{c|}{$\begin{array}{c}\text { Combined } \\
\text { Response* }\end{array}$} \\
\hline & $\mathrm{N}$ & $\%$ & $\mathrm{~N}$ & $\%$ & $\mathrm{~N}$ & $\%$ & $\mathrm{~N}$ & $\%$ \\
\hline $9-12$ & 3 & 3.06 & 0 & 0.00 & 2 & 3.03 & 3 & 1.42 \\
\hline $13-15$ & 8 & 8.06 & 9 & 7.96 & 4 & 6.06 & 17 & 8.06 \\
\hline $16-17$ & 46 & 46.94 & 57 & 50.44 & 32 & 48.48 & 103 & 48.81 \\
\hline Over 18 & 41 & 41.84 & 47 & 41.59 & 28 & 42.42 & 88 & 41.71 \\
\hline $\begin{array}{l}\text { Total } \\
\text { Responses }\end{array}$ & 98 & & 113 & & 66 & & 211 & \\
\hline
\end{tabular}

*Volunteer and Educator only. Responses of parents were not duplicated.

\section{Length of International Experience}

Respondents were given the opportunity to identify how long they thought an international experience should last. Over $50 \%$ of the surveys indicated two weeks as a desired length of the experience. In general, parents and volunteers were more comfortable than educators with longer experiences (Table 6).

Table 6

Respondent opinion of appropriate duration of international 4-H programs ( $N=113)$

\begin{tabular}{|l|c|c|c|c|c|c|c|c|}
\hline $\begin{array}{l}\text { Length of } \\
\text { Experience }\end{array}$ & \multicolumn{2}{|c|}{ Volunteer } & \multicolumn{2}{c|}{ Educator } & \multicolumn{2}{c|}{ Parent } & \multicolumn{2}{c|}{$\begin{array}{c}\text { Combined } \\
\text { Response* }\end{array}$} \\
\hline & $\mathrm{N}$ & $\%$ & $\mathrm{~N}$ & $\%$ & $\mathrm{~N}$ & $\%$ & $\mathrm{~N}$ & $\%$ \\
\hline 2 weeks & 22 & 43.14 & 35 & 56.45 & 13 & 39.39 & 57 & 50.89 \\
\hline 6 weeks & 16 & 31.37 & 12 & 19.36 & 8 & 24.24 & 28 & 25.00 \\
\hline 1 semester & 5 & 9.80 & 3 & 4.84 & 3 & 9.09 & 8 & 7.14 \\
\hline Other & 8 & 15.69 & 12 & 19.36 & 9 & 27.27 & 20 & 16.96 \\
\hline
\end{tabular}

*Volunteer and Educator only. Responses of parents were not duplicated.

\section{Cost of International Experience}

In response to the question "What is an appropriate fee range for an international experience?" $\$ 1,500$ to $\$ 1,999$ was the price range chosen most often. However, over $20 \%$ indicated costs up to $\$ 2,499$ were appropriate (Table 7 ).

Table 7

Respondent opinion of appropriate cost of international 4-H program participants $(\mathrm{N}=106)$

\begin{tabular}{|c|c|c|c|c|c|c|c|c|}
\hline Cost & \multicolumn{2}{|c|}{ Volunteer } & \multicolumn{2}{c|}{ Educator } & \multicolumn{2}{c|}{ Parent } & \multicolumn{2}{c|}{$\begin{array}{c}\text { Combined } \\
\text { Response* }\end{array}$} \\
\hline & $\mathrm{N}$ & $\%$ & $\mathrm{~N}$ & $\%$ & $\mathrm{~N}$ & $\%$ & $\mathrm{~N}$ & $\%$ \\
\hline$\$ 1,000-\$ 1,499$ & 8 & 16.66 & 15 & 25.00 & 4 & 12.50 & 22 & 20.75 \\
\hline$\$ 1,500-\$ 1,999$ & 14 & 29.17 & 23 & 38.33 & 13 & 40.63 & 36 & 33.96 \\
\hline$\$ 2,000-\$ 2,499$ & 10 & 20.83 & 12 & 20.00 & 6 & 18.75 & 22 & 20.75 \\
\hline$\$ 2,500-\$ 3,000$ & 11 & 22.92 & 7 & 11.67 & 6 & 18.75 & 18 & 16.99 \\
\hline Over $\$ 3,000$ & 5 & 10.42 & 3 & 5.00 & 3 & 9.37 & 8 & 7.55 \\
\hline
\end{tabular}

*Volunteer and Educator only. Responses of parents were not duplicated. 


\section{Participation in International 4-H Experience}

The last two questions on the survey asked respondents to rate their willingness to participate in an international project by travelling abroad or hosting a student on a Likert-type scale with one being "Definitely No" and five being "Definitely Yes". On average, respondents were willing to send Oklahoma 4-H members abroad, but were less willing to host an international student in Oklahoma (Table 8).

\section{Table 8}

Respondent willingness to participate in international 4-H programs

Responses were on a scale from 1 to 5 where $1=$ definitely No and $5=$ definitely Yes $(N=115)$

\begin{tabular}{|l|c|c|c|c|c|}
\hline \multicolumn{1}{|c|}{ Willingness to Participate } & Volunteer & Educator & Parent & $\begin{array}{c}\text { Standard } \\
\text { Combined } \\
\text { Response* }\end{array}$ & $\begin{array}{c}\text { Deviation } \\
\text { Combined } \\
\text { Response* }\end{array}$ \\
\hline $\begin{array}{l}\text { I am willing to host an } \\
\text { international student }\end{array}$ & 2.67 & 3.05 & 3.25 & 2.89 & 1.41 \\
\hline $\begin{array}{l}\text { I am willing to send 4-H youth } \\
\text { internationally }\end{array}$ & 3.43 & 3.60 & 3.63 & 3.66 & 1.18 \\
\hline
\end{tabular}

*Volunteer and Educator only. Responses of parents were not duplicated.

The final quantitative question on the survey instrument asked directly if the participants would like to see Oklahoma 4-H start an International 4-H program (Table 9). Choices were "Yes, Oklahoma 4-H should do this" or "No, I do not believe this is important for 4-H. "Ninety three percent responded "Yes, Oklahoma 4-H should do this."

Table 9

Respondents interest toward starting an international 4-H program ( $N=106)$

\begin{tabular}{|l|c|c|c|c|c|c|c|c|}
\hline Respondents Interest & \multicolumn{2}{|c|}{$\begin{array}{c}\text { Volunteer } \\
\text { Response }\end{array}$} & \multicolumn{2}{c|}{$\begin{array}{c}\text { Educator } \\
\text { Response }\end{array}$} & \multicolumn{2}{c|}{$\begin{array}{c}\text { Parent } \\
\text { Response }\end{array}$} & \multicolumn{2}{c|}{$\begin{array}{c}\text { Combined } \\
\text { Response* }\end{array}$} \\
\hline & $\mathrm{N}$ & $\%$ & $\mathrm{~N}$ & $\%$ & $\mathrm{~N}$ & $\%$ & $\mathrm{~N}$ & $\%$ \\
\hline $\begin{array}{l}\text { Yes, Oklahoma 4-H } \\
\text { should do this }\end{array}$ & 44 & 91.67 & 49 & 83.05 & 27 & 90.00 & 93 & 87.74 \\
\hline $\begin{array}{l}\text { No, I do not believe this } \\
\text { is important for 4-H }\end{array}$ & 4 & 8.33 & 10 & 16.95 & 3 & 10.00 & 13 & 12.26 \\
\hline Total Responses & 48 & & 59 & & 30 & & 106 & \\
\hline
\end{tabular}

*Volunteer and Educator only. Responses of parents were not duplicated.

The survey instrument also included two open-ended questions to give the survey participants an opportunity to share more with the researchers. The responses are summarized in Tables 10 and 11. Representative quotes are also included. 
Table 10

Responses to "Why do you think youth should have an international experience?"

Grouped by four themes: education and personal growth, cultural awareness, globalization, and experiences.

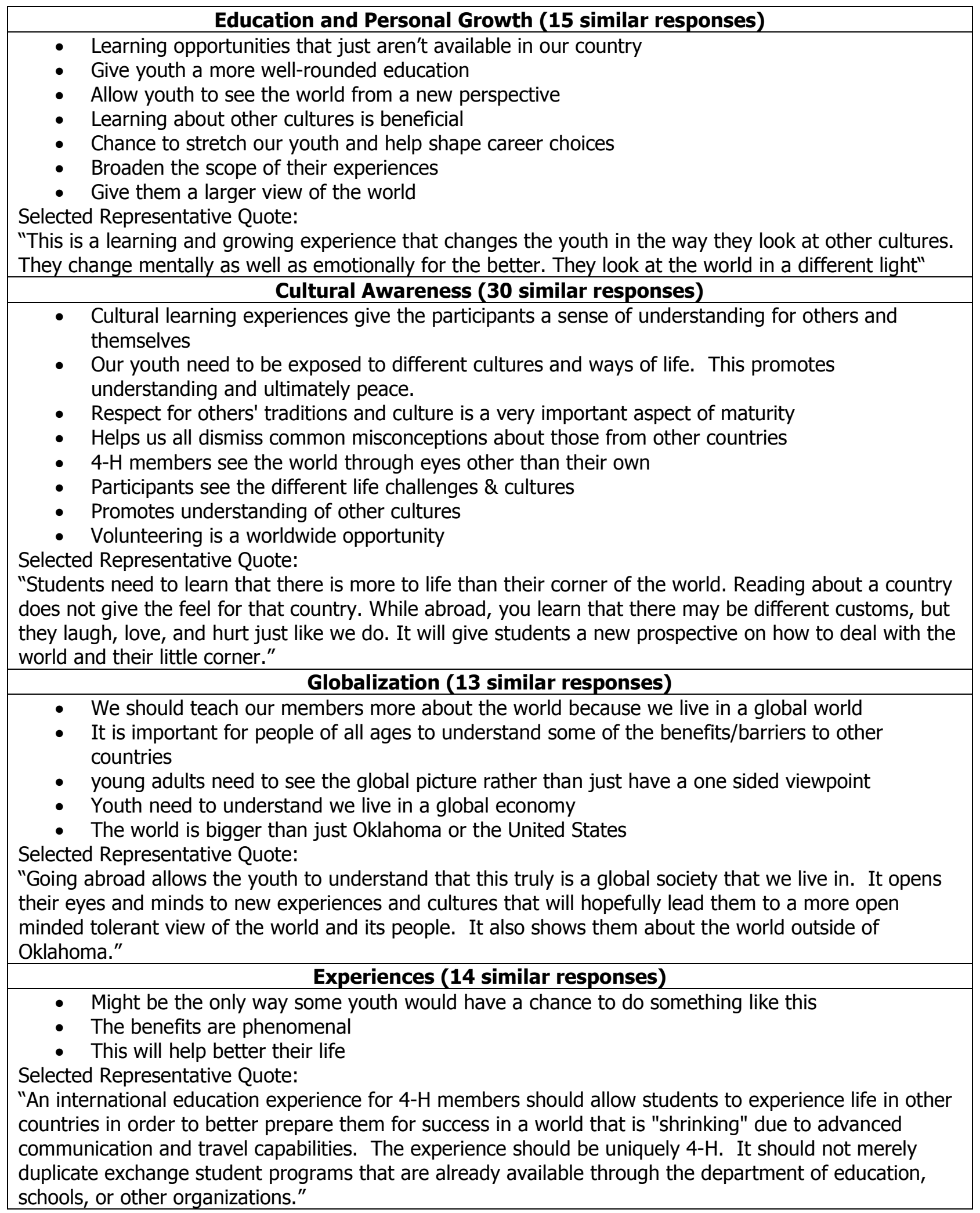


Table 11

Positive and negative responses of respondents' additional comments with representative quotes.

\begin{tabular}{|c|}
\hline Summary of Additional Comments (26 Responses) \\
\hline Positive Responses: \\
\hline $\begin{array}{l}\text { - } \text { Great idea (4 Similar) } \\
\text { - } \quad \text { Eye opening experience ( } 2 \text { Similar) } \\
\text { - } \quad \text { Learn new ways of doing things } \\
\text { - Pre study should be required } \\
\text { - } \quad \text { Staying with families is important } \\
\text { - } \quad \text { Sould be interested in hosting } \\
\text { Selected Representative Quote: } \\
\text { "I was privileged to get to travel in Europe when I was in my } 20 \text { s and it was the most amazing, eye- } \\
\text { opening, mind bending experience I've ever had." }\end{array}$ \\
\hline Negative Responses: \\
\hline $\begin{array}{l}\text { - There are important issues and projects to be undertaken in the U.S. before we send 4-H } \\
\text { - Thembers to other nations } \\
\text { - Safety and security issues would be of a concern (5 Similar) } \\
\text { - } \text { Only short term, past exchanges too long } \\
\text { - The risks and costs make it unsuitable for } 4-\mathrm{H} \\
\text { - I believe the same things can be achieved in the United States } \\
\text { Selected Representative Quote: } \\
\text { "I would need to have more details about the format of the program before I can give any real opinions. } \\
\text { At this point, I would tend to think that it will take a lot of time, effort and money to develop an } \\
\text { international program that will probably benefit a small number of youth. Oklahoma 4-H may do better } \\
\text { to invest that time, effort and money in a program that will benefit more of our youth." }\end{array}$ \\
\hline
\end{tabular}

Responses to the question "Why do you think youth should have an international experience?" were grouped into four themes; education and personal growth, cultural awareness, globalization, and experiences. The largest number of responses was categorized as cultural awareness; the other categories had approximately one-half the number of responses. In closing the survey, respondents were given the opportunity to express any additional comments. Table 11 summarizes those remarks into positive and negative responses. The most frequent positive comments were general in nature; the most frequent negative comments were related to youth safety.

\section{Summary and Conclusions}

These data indicate there is a positive perception among the 4- $\mathrm{H}$ volunteers and County Educators toward international programming through $4-\mathrm{H}$. The volunteers and parents generally gave a higher score to most questions than the County Educators; supporting previous research findings that indicate County Agents are resistant to international programs in 4-H (Etling, Reaman, \& Sawai, 1993). 
The population surveyed placed highest values on trip design. Particularly on elements that focused on cultural awareness by studying the country prior to the experience and by participating in cultural tours while abroad. They also suggested educational tours, participants receiving college credit for the experience, and conducting service learning projects as part of the experience. The appropriate fee range indicated was reasonable for designing an international experience.

Participant responses dropped somewhat when asked directly if they would host an international student or send a 4-H member abroad, indicating hesitance when confronted by being challenged to actually participate in the program.

Overall the survey results were positive toward beginning a new international program with the following recommendations:

- Experience should include learning about the culture

- Participants should study their destination country prior to travel

- Experience should be educational with tours and a service-learning component

- Participants should be at least 16 years old

- Experience should be limited to two weeks

The Oklahoma 4-H program has used the results of this survey in the design and development of a new short term international program that focuses on cultural awareness and servicelearning for older youth. At the time of this article this new program was still in its pilot stages. 4-H volunteers and educators have similar perceptions and opinions as volunteers and staff in other youth serving organizations. The results of this research could be applied to any youth agencies or organization with the goal of extending their international outreach and educational efforts.

\section{References}

Boyd, B.L., Giebler, C.,Hince, M., Liu, Y., Mehta, N., Rash, R., Rowald, J., Saldana, C., \& Yanta, Y. (2001). Does study abroad make a difference? An impact assessment of the international 4-H youth exchange program. Journal of Extension [On-line] 39(5) Article 5RIB8. Available at: http://www.joe.org/joe/2001october/rb8.php

Etling, A., Reaman, K.K., \& Sawi, G.E. (1993). Overcoming barriers to a global outlook in 4-H. Journal of Extension [On-line] 31(2) Article 2INTL2. Available at:

http://www.joe.org/joe/1993summer/intl2.php

Radhakrishna, R.B., \& Ingram, P.D. (2005). Experiences of 4-H Japanese exchange program on participants: An evaluative study. Journal of Extension [On-line] 43(3) Article 3RIB3. Available at: http://www.joe.org/joe/2005june/rb3.php

Reck, F.M. (1951). The 4-H Story. Ames IA: Iowa State College Press.

Wessel, T., \& Wessel, M. (1982.) 4-H: An American idea. Chevy Chase MD: National 4-H Council.

(C) Copyright of Journal of Youth Development Bridging Research and Practice. Content may not be copied or emailed to multiple sites or posted to a listserv without copyright holder's express written permission. However, users may print, download or email articles for individual use. 